\title{
A Study of Proliferative Activity of Herbs Eriocaulon Cinereum R.Br on Cervical Cancer Cells (HeLa) with MTT Assay Method
}

\author{
Arde T. Nugraha, Viren Ramadhan, Herianto Pandapotan, and Fitra Romadhonsyah \\ Department of Pharmacy, Universities Islam Indonesia, Yogyakarta \\ Email: arde.toga@uii.ac.id, \{virenramadhan19, fitra.romadhon\}@gmail.com, hpsiregar@ymail.com
}

\begin{abstract}
The objective of this research was to evaluate potency of Eriocaulon cinereum R.Br to inhibit the HeLa cells. Extraction method was obtained by ultrasoundassisted extraction at 40 degrees up to 30 minutes with ethanol $96 \%$. The extract was evaluated for total phenolic and flavonoid content and determine the proliferative on cervical cancer cell (HeLa) by MTT assay method. The result of total phenolic content is $18,983 \mathrm{mg} / \mathrm{g}$ of dry weight extract, expressed as gallic acid equivalents. The result of total flavonoid content is $63,518 \mathrm{mg} / \mathrm{g}$, expressed as quercetin equivalents. Eriocaulon cinereum $\mathbf{R}$. has potential as an anticancer with IC50 $427,79 \mu \mathrm{g} / \mathrm{ml}$ on HeLa cells. This study has revealed the potential of Eriocaulon cinereum R.Br from Bangka Belitung Island for cervical cancer treatment. The study has shown that an in vitro exposure of HeLa cells to Eriocaulon cinereum R.Br extract, inhibit the growth HeLa cells.
\end{abstract}

Index Terms-Eriocaulon Cinereum R.Br, ultrasoundassisted extraction, MTT assay, HeLa cells, cervical cancer

\section{INTRODUCTION}

Generally, cancer is the second leading cause of death in the United States. One of three Americans people falling victim to cancer [1]. Cervical cancer is one of the most common cancer in women worldwide. Prevalence of this cancer is second highest in the development country. Cervical cancer screening is an essential part of a woman's routine health care. This routine screening can decrease the prevalence of cervical cancer in Oceanian countries, European countries, and North America. With this routine screening, we can do an early prevention, so the cells can't grow out of control [2]. In 2016, American Cancer Society estimated 4.120 women died in 12.990 cases [3].

Standard treatments for cervical cancer are surgery, radiation therapy, and chemotherapy. But, alternative treatment can also use traditional medicine. There is a traditional therapy used as an adjuvant therapy for cervical cancer. These plants like grass that grows in the swamps, from Bangka Belitung Island, Indonesia. People in Bangka Belitung are used to using plants for preventing cancer. This grass name is Eriocaulon

Manuscript received November 15, 2016; revised March 28, 2017 cinereum R.Br included in Euricaulon family. Grass Gong has an anticancer activity. Traditional Chinese Medicine (TCM) has a combination therapy for cancer from Eriocaulon family, using Eriocaulon sieboldianum as an adjuvant therapy [4]. Eriocaulon australe species found in China has a cytotoxic activity for A549 cell, MCF-7, and HeLa cell [5].

The compounds of Eriocaulon cinereum R.Br abundant is isoflavones and flavones with some naphtha pyranones. Overall identification with high performance liquid chromatography DAD there are fifteen flavonoid. Figure 1 describe structure of compound from Eriocaulon cinereum R.Br. including Quercetin3-O-hexosyl-(Ocaffeoyl-)hexosyl hexoside (1), Quercetin3-O-hexosyl(O-caffeoyl)hexosyl-hexoside (2), Patuletin3-O- $\beta$-dgentiobioside (3), Quercetin3-O-deoxyhexosyl-hexoside (4), Patuletin3-O-caffeoyl-O-hexosyl-hexoside (5), Hispidulin7-O- $\beta$-d-glucopyranoside (6), 5,4Dihydroxy6,3-dimethoxyflavone7-O- $\beta$-d

glucopyranoside (7), Toralactone9-O- $\beta$-d-glucosyl$(1 \rightarrow 6)$-lucoside (8), Gerontoisoflavone A (9), 7,3Dihydroxy-5,4,5-trimethoxyisoflavone (10), Hispidulin (11), Iristectorigenin A (12), 5,7,3-Trihydroxy-6,4,5trimethoxyisoflavone (13), (R)-Semixanthomegnin (14), (R)-Semivioxanthin (15). The high concentration compound of Eriocaulon cinereum $\mathrm{R} . \mathrm{Br}$ is hispidulin, between 40-50\%. Hispidulin (11), it's one of flavonoids group. That is the major characteristic compound from Eriocaulon cinereum R.Br with iristectorigenin A (12) and irigenin(13) [6]. Hispidulin reported having activities inhibits of ROS production and improve the functions of mitochondria [7]. ROS reported can be a trigger become cancer.

Tetrazolium-based colorimetric assay (MTT test) is a method that simply counting in vitro living cells [8]. This method is carried out on searches immunological effects, cancer and biocompatibility evaluation. MTT assay is a method that can be accounted for the results, other than that this method is also relatively quick and reproducible. The objective of this research was to assess the potential of Eriocaulon cinereum $\mathrm{R} . \mathrm{Br}$ as an anti-cancer agent. The potential assessment carried out by how strongly the ethanolic extract from Eriocaulon cinereum $\mathrm{R}$.Br inhibit proliferation the HeLa cell. 
Grass Gong has a potential value as an anticancer, especially cervical cancer. It's important to explore the anticancer activity in cervical cancer's cell in order to know about how big potential to cure cancer. Identification of the compound is also important to find the secondary metabolites in this plant.<smiles>COc1c(-c2ccccc2)cc2oc(-c3ccc(O)c(Br)c3)cc(=O)c2c1O</smiles><smiles>CCc1c(-c2ccc(O)c(O)c2)oc2cc(O)c(OC)c(O)c2c1=O</smiles>

Flavonols

(3) $\mathrm{R}_{1}=\mathrm{O}$-glu-(6,1)-glu<smiles>COc1cc(Br)c2c(O)c3c(cc2c1)C[C@H](C)OC3=O</smiles>
(15) $\mathrm{R} 1=\mathrm{OH}$<smiles></smiles>

(14)

Flavones (6) R1=HR2=O-glu (7) $\mathrm{R} 1=\mathrm{OCH} 3 \mathrm{R} 2=\mathrm{O}-\mathrm{glu}$ (11) $\mathrm{R} 1=\mathrm{HR} 2=\mathrm{OH}$<smiles>[R]c1c(O)cc2occ(C3CC([R])C(Br)C(OC)C3)c(=O)c2c1[123I]</smiles>
(9) $\mathrm{R}_{1}=\mathrm{OHR}_{2}=\mathrm{HR}_{3}=\mathrm{OCH}_{3} \mathrm{R}_{4}=\mathrm{H}$ (10) $\mathrm{R}_{1}=\mathrm{OCH}_{3} \mathrm{R}_{2}=\mathrm{OHR}_{3}=\mathrm{OCH}_{3} \mathrm{R}_{4}=\mathrm{H}$ (11) $\mathrm{R}_{1}=\mathrm{OCH}_{3} \mathrm{R}_{2}=\mathrm{OHR}_{3}=\mathrm{OHR}_{4}=\mathrm{OCH}_{3}$<smiles>COc1cc(Br)c2c(O)c3c(=O)oc(C)cc3cc2c1</smiles>

(8) $\mathrm{R}_{1}=\mathrm{O}-\mathrm{glu}-(6,1)$-glu<smiles>COc1ccc(-c2coc3cc(O)c(OC)c(O)c3c2=O)cc1O</smiles>

(12)

Figure 1. Structure of compound from Eriocaulon cinereum R.Br.

\section{MATERIAL AND METHODS}

\section{A. Cell Lines, Chemical, and Biochemicals}

Cervical cancer cell (HeLa) obtained from Parasitologi Laboratorium Medicine Faculty of Gadjah Mada University. Etanol 96\%, PLGA, PVA 2,5\%, RPMI 1641 (Sigma Aldrich), Fungizon 0,5\%, Penicillin/Streptomycin Solution 1\%, Fetal bovine serum 10\% (FBS), SDS 10\%, MTT $0,5 \%$.

\section{B. Sample Collection}

The herbs of Eriocaulon cinereum $\mathrm{R} . \mathrm{Br}$ was collected on the month of July 2016 from Bangka Belitung Island. The Fresh herbs were packed in a polyethylene bag and transported to the laboratory.

\section{Preparation of Sample}

The whole herbs of Eriocaulon cinereum R.Br were washed with water and dried in the drying cabinet at $50 \mathrm{oC}$ for 4 days. The dry herbs were ground using a grinder until smooth and escaped in the mesh 60 . The whole herbs powder of Eriocaulon cinereum $\mathrm{R}, \mathrm{Br}$ were packed in glass containers until extraction.

\section{Extraction Procedure}

The dried powder of Eriocaulon cinereum $\mathrm{R} . \mathrm{Br}(25 \mathrm{~g})$ was extracted with ethanol $96 \% \quad(250 \quad \mathrm{ml})$ using Ultrasound Assisted Extraction with modification [9]. After extraction, it was filtered and evaporated by vacuum rotary evaporator to give viscous masses. The crude extract $(5,24 \mathrm{~g})$ were packed in a glass container.

\section{E. Determine of Total Phenol by Folin-Reagent Method}

Total phenol content was determined by Folin Ciocalteu reagent method [10]. Gallic acid calibration was prepared by various concentration $(100,50,25,12.5$ and $6.25 \mu \mathrm{g} / \mathrm{ml}$ ). The $3 \mathrm{mg}$ extract was dissolved in $10 \mathrm{ml}$ methanol. $1 \mathrm{ml}$ of Gallic acid and the extract is taken in flasks then added by water $(9 \mathrm{ml}) .1 \mathrm{ml}$ Folin-Ciocalteu reagent and $10 \mathrm{ml} \mathrm{Na} \mathrm{CO}_{3}(7 \%)$ was added to each flask. Then all flasks were kept in a dark place for $90 \mathrm{~min}$. The 
absorbance was measured by using UV-Vis spectrophotometer at wavelength $765 \mathrm{~nm}$.

\section{F. Determine of Flavonoids Content}

The ethanolic crude extract was estimated by aluminum chloride colorimetric method as describe by Asma et al [11]. Extract $(0.5 \mathrm{ml})$ with concentration 300 $\mu \mathrm{g} / \mathrm{ml}$ was added $1.5 \mathrm{ml}$ ethanol. Then dissolving by $1 \mathrm{ml}$ $\mathrm{AlCl} 3$ anhydrate $(10 \%)$ and added by $0.1 \mathrm{ml}$ potassium acetate $1 \mathrm{M}$ and water $2.8 \mathrm{ml}$. Then mixed the solution and waiting for $30 \mathrm{~min}$. The absorbance was measured by using UV-Vis spectrophotometer at wavelength $415 \mathrm{~nm}$. Quercetine standard was used for the calibration curve.

\section{G. Determine of Compounds from Extract}

Determine chemical constituents of the extract is used a reagent spray. Dragendorff reagent for alkaloid compounds. Anisaldehid-Sulfuricacid for terpenoids.

\section{H. Determine of Proliferative or Inhibitor Effects of Eriocaulon Cinereum R.Br Extract on Cervical Cancer Cell (HeLa)}

The Eriocaulon cinereum R.Br extract was applied to HeLa cells to determine a proliferative activity [12]. The Eriocaulon cinereum R.Br extract was dissolved in DMSO at a concentration of $500 \mu \mathrm{g} / \mathrm{ml}, 250 \mu \mathrm{g} / \mathrm{ml}, 125$ $\mu \mathrm{g} / \mathrm{ml}, 62.5 \mu \mathrm{g} / \mathrm{ml}, 31.25 \mu \mathrm{g} / \mathrm{ml}, 15.62 \mu \mathrm{g} / \mathrm{ml}, 7.81 \mu \mathrm{g} / \mathrm{ml}$ and $3.90 \mu \mathrm{g} / \mathrm{ml}$.

A $10 \mathrm{ml}$ volume of growth media (RPMI 1640) suspension with HeLa cells was centrifuged at $1500 \mathrm{rpm}$ for 10 minutes. The supernatant was poured off and resuspended in $10 \mathrm{ml}$ media and incubation on the $\mathrm{CO} 2$ incubator at $37 \mathrm{oC}$. Cells were observed under the microscope and if the number of cells enough (confluent) take $10 \mu \mathrm{L}$ Cells then counted on a hemacytometer.

Cells were seeded at 10,000-50,000 cells/ ml placed in 96-well plates. Twenty-four hours later, added the Eriocaulon cinereum $\mathrm{R} . \mathrm{Br}(100 \mu \mathrm{L})$. The plate was incubated for a further 24 hours. The medium was removed from the well and $100 \mu \mathrm{L}$ of a new medium and $10 \mu \mathrm{L}$ MTT $(0.5 \%)$ was added. The Plate was incubated for 3 hours and then added 10\% SDS. The plate was incubation 4 hours and kept in dark place at room temperature. The absorbance was measured by Elisa reader at wavelength $550 \mathrm{~nm}$. Controls for the assay include cells with DMSO and cells alone.

\section{RESULT AND DISCUSSION}

The result of study presented in Table I, including total phenolic, total flavonoid and proliferation activity on
HeLa cells. The total phenol content of extract Eriocaulon cinereum R.Br was determined by FolinCiocalteu method. The total phenolic content of the extract was expressed as miligram of gallic acid equivalent. The result was $18.983 \mathrm{mg} / \mathrm{g}$ gallic acid equivalent as dry weight extract. The total content of phenolic compound was determined from the regression equation of the calibration curve $(y=0.00574 x+0.00625$, $\mathrm{R} 2=0.987$ ) and expressed in Galic Acid Equivalent.

The total flavonoid of extract Eriocaulon cinereum $\mathrm{R} . \mathrm{Br}$ was reported as quercetin equivalent. The result was $63.518 \mathrm{mg} / \mathrm{g}$ quercetin equivalent as dry weight extract. Determining the total flavonoid content using $\mathrm{AlCl} 3$ is based on the formation of the stable complex between aluminum chloride and the keto and hydroxyl group of flavones and flavonoids [10]. The total flavonoids in extract was determined from regression equation of the calibration curve $(y=0.00422 x+0.0106$, $\mathrm{R} 2=0.985)$ and expressed in quercetin equivalent $(\mathrm{QE})$.

The chemical compound of extract was positif as terpenoid compound, but negative for alkaloid. it is not visible from the appearance of red spots on the test results after being sprayed Dragendorff reagent.

The result of treatment of HeLa cells with ethanolic extract of Eriocaulon cinereum $\mathrm{R} . \mathrm{Br}$ showed by $\mathrm{IC}_{50}$ value, it was $427.79 \mu \mathrm{g} / \mathrm{ml}$. In this study, extract of Eriocaulon cinereum R.Br. has monitored growthproliferative effect in HeLa cells. The proliferative activity in HeLa cells from Eriocaulon cinereum R.Br has never been reported. Previously, the proliferative effects in HeLa cells have been reported from other species from Eriocaulon. One of the species is Eriocaulon austral from China, the extract displaying a cytotoxic effect in A549, MCF-7 and HeLa Cells [5]. The another species is Eriocaulon sieboldianum used as adjuvant cancer therapy [4].

Flavonoids from eriocaulon family has proven to anticancer activity in HeLa cells. As flavonoid derived from species Eriocaulon australe. Reported that hispidulin have HeLa cell growth inhibition of $\mathrm{IC}_{50} 10.38 \mu \mathrm{g} / \mathrm{ml}$. In addition, there are also flavonoids Jaceosidin and $3^{\prime} .4^{\prime}$ methylenedioxyorobol who have $\mathrm{HeLa}$ cell growth inhibition with $\mathrm{IC}_{50} 15.29 \mu \mathrm{g} / \mathrm{ml}$ and $10.63 \mu \mathrm{g} / \mathrm{ml}$ [5].

From these results, extract of Eriocaulon cinereum $\mathrm{R}$.Br has potential as an anticancer. The results prove that the people from Bangka Belitung Island were appropriate. But, there is still need further studies to know in vivo activity of an animal model and also in humans for find best doses therapy. Other than that, it needs to figure out the active compound anticancer from Eriocaulon cinereum R.Br.

TABlE I. TOTAL PHENOLIC, FlaVonoid CONTENT AND VALUE OF INHIBITED OF HELA CELLS FROM ETHANOLIC EXTRACT OF ERIOCAULON CINEREUM R.BR

\begin{tabular}{l|l|}
\hline \multicolumn{1}{|c|}{ Total phenolic content $^{\mathrm{a}}$} & 18.983 \\
\hline \multicolumn{1}{|c|}{ Total flavonoid content $^{\mathrm{b}}$} & 63.518 \\
\hline Inhibit value of HeLa cells $^{\mathrm{c}}$ & 427.79 \\
\hline a. $\mathrm{mg}$ gallic acid equivalent $(\mathrm{GAE}) / \mathrm{g} \mathrm{DW}$ & \\
b. $\mathrm{mg}$ quercetin equivalent/ $\mathrm{g} \mathrm{DW}$ & \\
c. $\mathrm{IC}_{50}(\mu \mathrm{g} / \mathrm{ml})$ &
\end{tabular}




\section{CONCLUSION}

The study has shown that an in vitro exposure of HeLa cells to Eriocaulon cinereum $\mathrm{R} . \mathrm{Br}$ extract, inhibit the growth HeLa cells. Eriocaulon cinereum $\mathrm{R} . \mathrm{Br}$ has potential as an anti-cancer drug. The effect of Eriocaulon cinereum $\mathrm{R} . \mathrm{Br}$ requires in-depth study in vivo in an animal model to figure out the activity against tumor cells. Then, it is also necessary to figure out on chemical compounds responsible for the activity.

\section{CONFLICTS OF INTERESTS}

All author have none to declare.

\section{REFERENCES}

[1] J. L. Longe, The Gale Encyclopedia of Cancer: A Guide to Cancer and Its Treatments, 2005, ch. 2, p. 192.

[2] WHO, IARC Handbooks of Cancer Prevention: Cervix Cancer Screening, IARC, 2005, ch. 10, pp. 119-23.

[3] ACS, Cervical Cancer, American Cancer Society, 2016, ch. 3.

[4] Y. Fan, et al., "Effect of active fraction of Eriocaulon sieboldianum on human leukemia K562 cells via proliferation inhibition, cell cycle arrest and apoptosis induction," En. Tox. Phar., vol. 43, pp. 13-20, 2016.

[5] Q. Xu, H. Xie, P. Wu, and X. Wei, "Flavonoids from the capitula of Eriocaulon australe," Food Chemistry, vol. 139, pp. 149-54, 2013.

[6] Q. Xue, et al., "Chemical analysis of Eriocaulon burgerianum and adulterating species by high-performance liquid chromatography with diode array detection and electrospray ionization tandem mass spectrometry," J. Phar. Bio. An., vol. 75, pp. 133-42, 2012.

[7] W. W. Qin, J. X. Xi, B. Q. He, B. B. Zhang, H. L. Luan, and F. H. $\mathrm{Wu}$, "Ameliorative effects of hispidulin on high glucose-mediated endhotelialdysfungsion via inhibition of PKCBII-associated NLRP3 inflammasome activation and NF-KB signaling in endothelial cells," J. Fun. Fo., vol. 27, pp. 392-405, 2016.

[8] G. Ciapetti, E. Cenni, L. Pratelli, and A. Pizzoferranto, "In vitro evaluationof cell/biomaterial interaction by MTT assay," Biomaterial, vol. 14, no. 5, pp. 359-364, 1993.

[9] S. C. Mandal, V. Mandal, and A. K. Das, Essentials of Botanical Extraction: Principles and Applications, Netherlands: Elsevier. Academic Press, 2015, ch 6, p. 96.

[10] M. H. Amzad and R. S. M. Mizanur, "Total phenolic, flavonoids and antioxidant activity of tropical fruit pineapple," Food Res. Inter., vol. 44, pp. 672-676, 2011.

[11] H. S. Asma and M. H. Amzad, "Total phenol, total flavonoids contents and free radical scavenging activity of seeds extracts of pigeon pea traditionally used in oman for the treatment of several chronic diseases," Asian Pac. J. Trop. Dis., vol. 5, no. 4, pp. 316$321,2015$.

[12] S. A. Cichello, Q. Yao, and X. Q. He, "Proliferative activity of a blend of Echinacea angustifolia and Echinacea purpurea root extract in human vein epithelial, HeLa, and QBC-939 cell lines, but not in Beas-2b cell lines," J. Trad. Comp. Med., vol. 6, pp. 193-197, 2016.
[13] S. Khamis, R. N. Said, and M. A. Hossain, "In vitro evaluation of the total phenolic and flavonoid contents and the antimicrobial and cytotoxicity activities of crude fruits extracts with different polarities from Ficussycomorus," Pacific Science Review A : Nat. Sci. Eng., vol. 17, pp. 103-08, 2015.

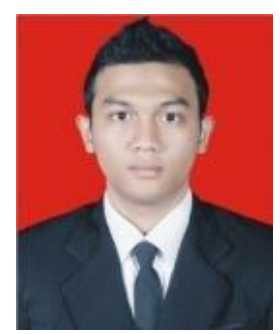

Arde T. Nugraha born at Surabaya, Indonesia, April 16, 1990. Graduate bachelor of pharmacy in September 2011 and pharmacist in September 2012 at Departmen of Pharmacy Universitas Islam Indonesia. Graduate from Master degree September 2015 at Faculty of Pharmacy, Gajah Mada University, Indonesia. The study concentration at drug discovery.

Working as a lecture at Department of Pharmacy, Universitas Islam Indonesia from December 2015.

Mr. Nugraha, has a member from FIP(International Pharmaceutical Federation), IYPG (Indonesia Young Pharmacist Group) and IAI (Indonesia Pharmacist Association). Mr. Nugraha winning travel grant from FIP and invited to FIP World Congress at Buenos Aires 2016.

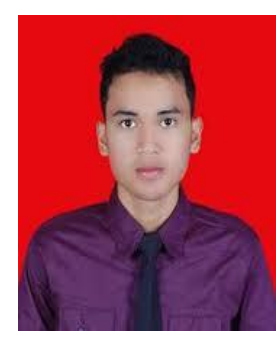

Herianto Pandapotan was born at Jakarta, Indonesia Jan 22, 1994. Graduate bachelor of pharmacy, June 2016 at Department of Pharmacy Universitas Islam Indonesia. The last research project is about Prolifetarive activity of SNEDDS garlic extract on cervical cancer cells.

Working as a research assistant at Department of Pharmacy, Universitas Islam Indonesia from September 2016.

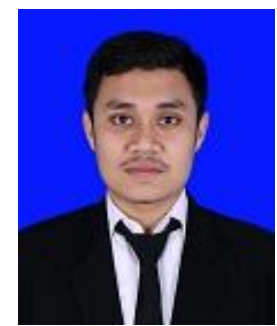

Viren Ramadhan was born at Batam Island, Indonesia March 1, 1994. Graduate bachelor of pharmacy, September 2016 at Department of Pharmacy Universitas Islam Indonesia. The last research is about synthetic curcumin activity on cancer cells.

Working as a research assistant at Department of Pharmacy, Universitas Islam Indonesia from September 2016.

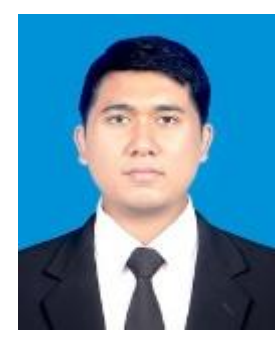

Fitra Romadhonsyah was born at Bandung, Indonesia, Feb 28, 1995. Graduate Bachelor of pharmacy, May 2016 at Department of Pharmacy Universitas Islam Indonesia. The last research project is about Isolation phenolic compound from ipomoea aquatica.

Working as a research assistant at Department of Pharmacy, Universitas Islam Indonesia from September 2016. 